\title{
Malta's Water Scarcity Challenges: Past, Present, and Future Mitigation Strategies for Sustainable Water Supplies
}

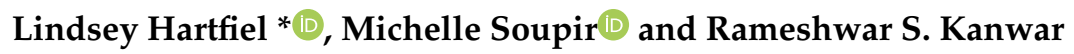 \\ Department of Agricultural and Biosystems Engineering, Iowa State University, Ames, IA 50011, USA; \\ msoupir@iastate.edu (M.S.); rskanwar@iastate.edu (R.S.K.) \\ * Correspondence: lmurry@iastate.edu
}

Received: 6 October 2020; Accepted: 17 November 2020; Published: 24 November 2020

\begin{abstract}
The small Mediterranean country of Malta, an island located between Italy and North Africa, has been facing and will continue to face water stress and scarcity in the coming years, receiving the designation as the most water stressed country in Europe. In the past, Malta's water challenges were centered around water quantity concerns, but in more recent years, the severity of their water stress has been strengthened by the deterioration of the groundwater quality and quantity. Through the over-extraction of their groundwater, saltwater intrusion has steadily occurred into their freshwater aquifer systems, worsening their groundwater quality for both domestic and agricultural purposes. The objective of this paper is to conduct an extensive review on the history of Malta's water problems and how Malta is working to combat its water scarcity concerns. Additionally, this paper investigates the impact of Malta's water scarcity on its food and energy security challenges. Our study concludes that while Malta has obstacles to overcome in their pursuit of water security and sustainable development, the future remains hopeful, with several alternatives still available. Some of the alternatives explored in this review include wastewater reuse, increased awareness, use of alternative energy sources, rainwater harvesting, and implementation of nation-wide strategic water policies.
\end{abstract}

Keywords: groundwater quality; rainwater harvesting; water policy

\section{Introduction}

To be a truly sustainable society, the needs of the people must be met. In the simplest terms, society needs food, energy, and water to survive and thrive. Not only do they need these, they also need them to be provided in a sustainable manner, meaning the success of future generations should not be compromised by the current generation's use of resources. In the small island country of Malta, the three pillars of food, energy, and water security are in jeopardy, as Malta has been determined to be the most water scarce country in Europe and in the top ten in the world [1-4]. Malta, located in the Mediterranean region, has a semi-arid climate with a total average rainfall per year of approximately $550 \mathrm{~mm}$. Most of the rainfall occurs between October and February; in contrast, they receive very little rainfall in the summer, when crop demand and tourism are at their highest levels [3,5-8]. Countries with a semi-arid climate typically have variable annual precipitation with greater evapotranspiration than rainfall. Other countries in Europe that fall within this climatic designation include Portugal, Spain, Italy, Greece, and Cyprus, which are also located within the Mediterranean region [9]. The Mediterranean region is expected to have further impacts on their water supply due to climate change in the coming years [10]. Projections for climate change in the southern portion of Europe predict decreased precipitation, especially during the summer months, with increased 
temperatures above the average increase in global temperature [11]. Several European countries also face current and projected water stress such as Greece, Spain, Portugal, Cyprus, and Italy [12].

While Malta will have to prepare for the future impacts of climate change, the country is already facing depleting groundwater levels, which is the only source of naturally replenishing waters. There are essentially no surface waters that can be used as a water source, as any streams in Malta only flow a few days a year after large storm events $[6-8,13]$. As a result of the diminishing groundwater in Malta, the groundwater that is extracted is becoming increasingly saline, with chloride levels exceeding $2000 \mathrm{mg} / \mathrm{L}$ [7]. Increasingly, saline groundwater threatens the food security of the country. Crops cannot tolerate the increasing levels in soil salinity, which reduces yields drastically $[5,14,15]$. To bolster water availability, Malta has turned to Reverse Osmosis desalination technology to desalinate sea water. The resulting brine solution is primarily discharged back to the sea, where strong currents exist to quickly disperse the highly saline solution [2]. While this serves as an alternative way to create additional resources of good quality water, it comes at a price due to the high amount of energy needed to treat the water $[2,13]$. This need for energy has also created a dependence on oil imports which now drives the cost for both water and electricity $[6,16]$. Therefore, the water scarcity issue in Malta represents not only a water security problem, but also a food and energy security challenge.

The purpose of this paper is to conduct an extensive literature review of the historical and current water resource management and infrastructure in Malta, current and projected water, food, and energy security concerns, and finally, suggested solutions to help reduce the water, food, and energy security concerns.

\section{Research Area}

In this study, we focus on the water, food, and energy security of the small island country of Malta. This country is located in the Mediterranean with a semi-arid climate and area of $316 \mathrm{~km}^{2}$ (Figure 1). The population of Malta as of the end of 2018 was approximately 493,000 people [17]. Because of the small size of the country, Malta is also one of the most densely populated countries in the world, with a population density of $1400-1500$ people per $\mathrm{km}^{2}$ [2,17]. As of $2018,94.6 \%$ of Malta's population lived in urban areas, with the remainder living in rural areas [18]. The country also experiences high levels of tourism, especially in the summer months. In 2019, Malta had nearly 1.8 million non-resident tourists [17]. As part of the semi-arid climate, the area typically experiences hot and dry summers with mild, wet winters, with a total average rainfall of $550 \mathrm{~mm}$ per year (Figure 2). The hot, dry summers correspond to peak tourism, placing an additional water demand on the country. 


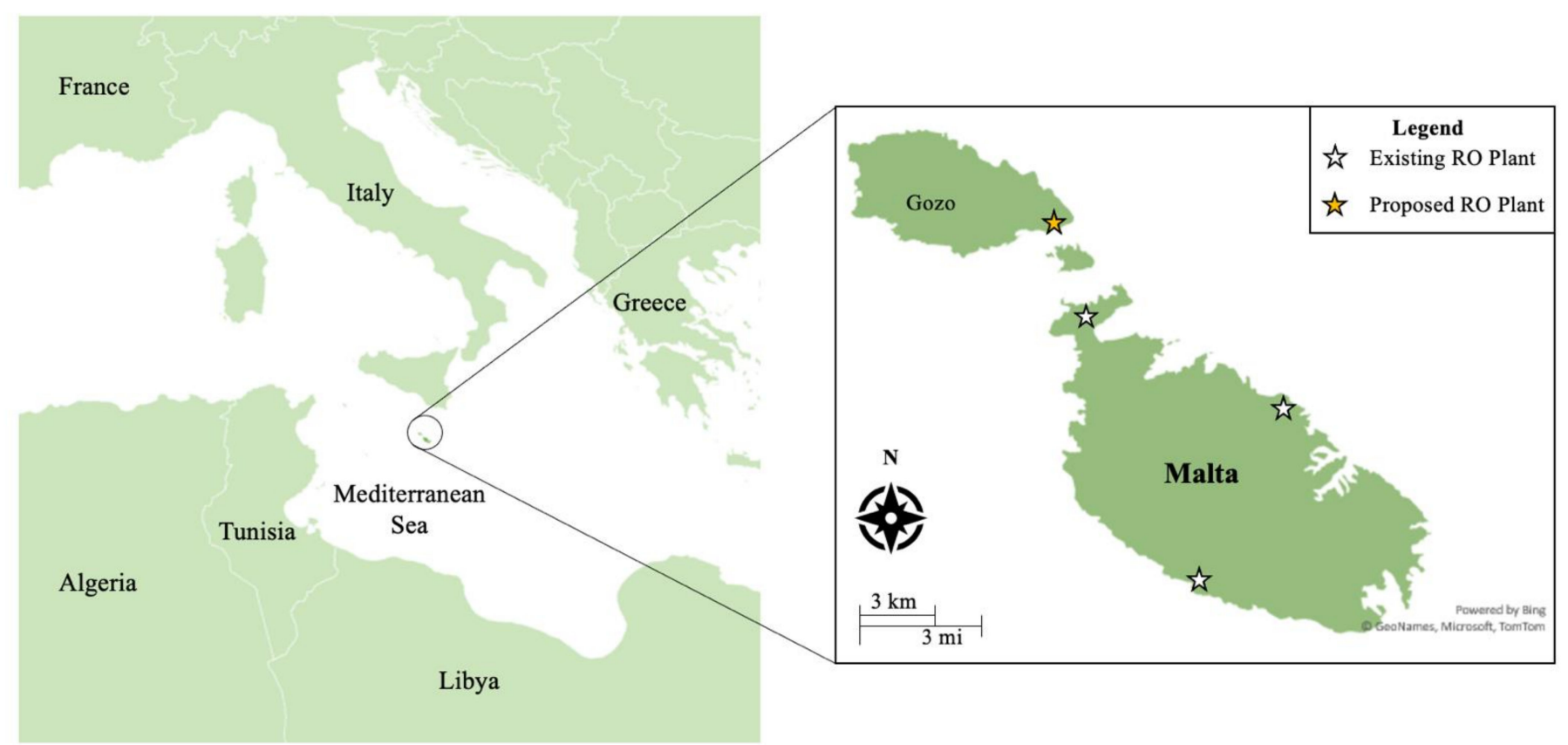

Figure 1. Location of Malta in relation to Southern Europe and Northern Africa as well as the location of Reverse Osmosis plants in Malta [19,20]. 


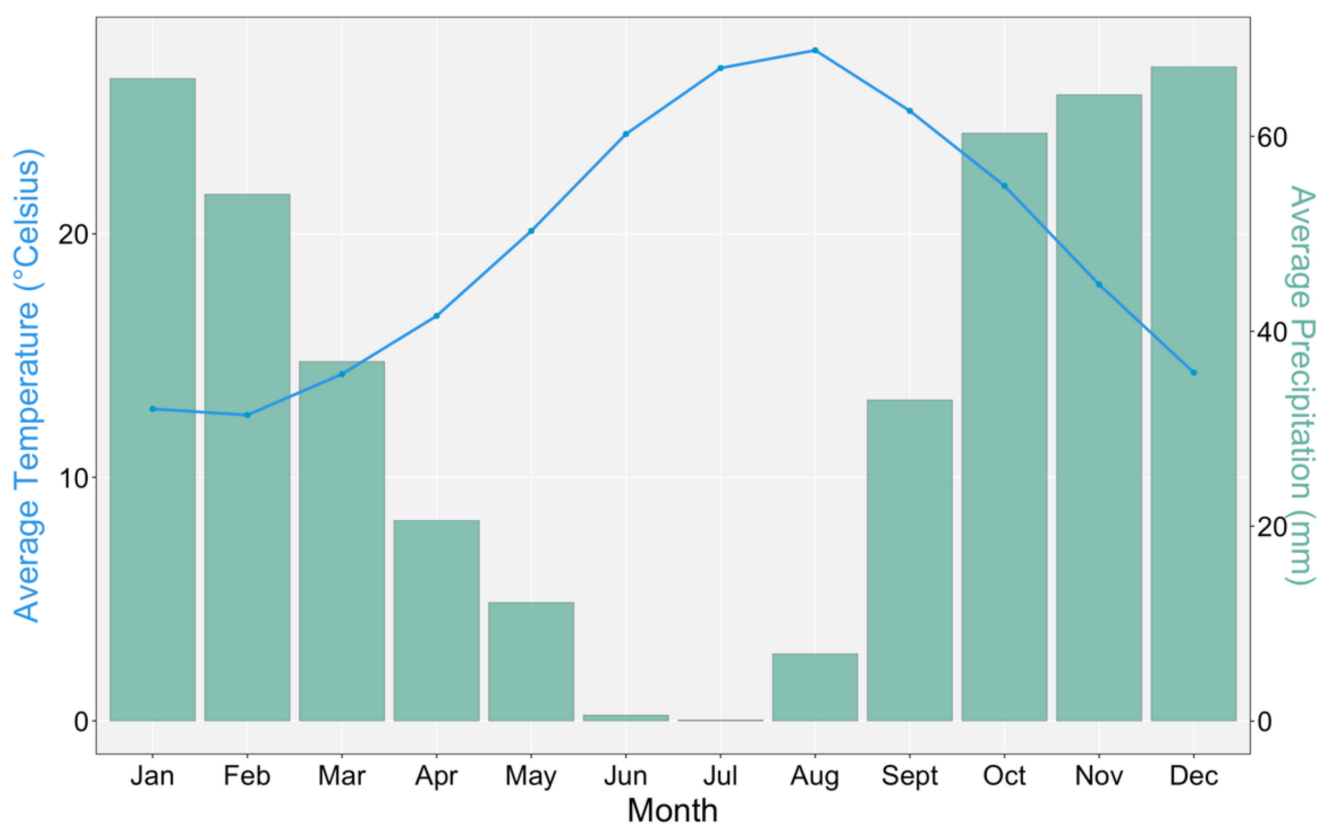

Figure 2. Average temperature and precipitation by month in Malta during the time period of 1991-2016 modified from [21].

In terms of water resources, Malta's water supply comes primarily through Reverse Osmosis, which will be covered in greater detail in subsequent sections, and groundwater. There are essentially no surface waters that can be used as a water source in Malta, as there are no major rivers and much of the rainfall infiltrates eventually to the groundwater [6-8,13]. Instead, groundwater serves as the only naturally replenishing source of water for the country. The abstraction of groundwater currently amounts to approximately 34 million $\mathrm{m}^{3}$ of groundwater each year. This is estimated to be 11 million $\mathrm{m}^{3}$ more than is considered to be sustainable or equal to recharge [13]. Due to the over-extraction of groundwater which has reduced water quality, Reverse Osmosis is used to supplement the country's water supply. In terms of primary groundwater users, irrigated agriculture is estimated to use $75 \%$ of the groundwater abstracted yearly while only accounting for a meager $15 \%$ of the land $[3,22]$. In general, roughly $1 / 3$ of the land in Malta is used for agricultural purposes [18]. The extent of Malta's water, food, and energy security concerns as a result of their historical and current water use is discussed in the following sections.

\section{Malta's Water Resource Management and Infrastructure}

\subsection{Historical Water Resource Management and Infrastructure}

For any civilization to survive, water is a necessity; the small island of Malta is no exception. Initially, the people lived near the coast where natural springs were found; from that point, tanks and cisterns were created to store water further inland, some of which date back to the Neolithic period [23]. This was how the Indigenous people of Malta used water for much of their history and in a sustainable way. It wasn't until the Knights of St. John came to the island in 1512 that water quantity limitations were noticed and documented. The springs were reported to diminish during the summer months, and much of the drinking water was kept in tanks [6-8,23]. After their arrival, the Knights of St. John created legislation to require the construction of cisterns for rainwater storage for every new building built in the city [6]. In addition to the rainwater storage tanks, an aqueduct was constructed in 1610 to provide water to the city of Valletta, using springs from a perched aquifer to feed it; a second aqueduct was built after a drought lasting from 1834-1841 to supply water to the three cities of Cospicua, Vittoriosa, and Senglea, as well as a few villages $[7,23]$. These aqueducts and rainwater storage structures served as the primary source of drinking water to the people of Malta 
through the 19th century, but were quite susceptible to contamination from waste products on the roads, sewer leaks, manure from animals, etc. [23]. Still, these were the main sources of drinking water until the needs of the people grew, and then groundwater was extracted to supplement the growing demands of the population.

As the population of Malta grew further, additional water was needed to meet their needs. In the second half of the 19th century, water exploration and well drilling was just beginning. From this point, pumping stations and boreholes were added across the country, tapping into both perched aquifers and the mean sea level aquifer. Within the first decade of the 1900s, the perched aquifer became contaminated by leaching manure, which resulted in bacterial pollution that contributed to two typhoid outbreaks. In 1909, chlorination was introduced, and closed pipes began replacing open channels [23]. The drilling of boreholes began intensively in 1943. By the 1960s, issues with salinity were noticed (with $800 \mathrm{ppm}$ of salt concentration in groundwater), driving Malta to turn to multi-stage flash seawater distillation units to provide better quality water for drinking. During this time, Malta also imported water from Sicily via tankers. In the 1970s, another campaign to drill boreholes began, which in turn greatly reduced the quality of the water. By 1980, the average salinity level in the mean sea level aquifer had increased to $1600 \mathrm{mg} / \mathrm{L}$ [23]. For perspective, the World Health Organization's (WHO's) recommended salinity threshold had been set at 600 ppm [14]. At this point in time, Malta began to build Reverse Osmosis plants to desalinate water, and these plants are currently used to supplement the groundwater resources [24]. These plants filter salts out by passing the water through permeable membranes under high pressure [13]. It should be noted that the quality of the Reverse Osmosis is susceptible to any contamination in the surrounding seawater, such as an oil spill. This system, while providing additional water resources, did create an additional need and dependence on imported oil [6,16].

Measures to improve the water scarcity issues in Malta continued in the 1990s. In 1992, the Water Services Corporation (WSC) was created with the purpose to manage the "acquisition, transformation, manufacture, distribution and sale of potable and non-potable water," while the Malta Resource Authority was created to grant licenses and authorize, monitor, create regulations, and take preventative actions in terms of water overuse [7,23]. Additionally, the WSC serves to oversee the treatment and disposal/reuse of sewage and wastewater as well as reuse of stormwater runoff. At the time of its creation, the water scarcity and water quality problems were recognized and were found to be of great importance to Malta. In the 1990s, the groundwater was overexploited and was becoming increasingly polluted; the use of Reverse Osmosis led to people believing they had an abundance of water [14]. Additionally, a noticeable unfair distribution of water in terms of quality and quantity was seen, especially in the southern portion of Malta, leading to inequality of water resources for that region. This inequality was a result of the majority of the Reverse Osmosis plants being located in the northern portion of Malta, while the Southern portion was supplied water primarily through boreholes with high salinity groundwater. The sewage system was also very poor, with many people simply dumping their waste into cesspits. Lastly, $54 \%$ of the water produced was unaccounted for, primarily from leakages, unregistered water meters, billing errors, and water thefts [14]. Malta has seen water scarcity issues throughout their history, but more recently, this water scarcity has also come with degrading quality of the water, making the situation even more challenging.

\subsection{Current Water Resource Management and Infrastructure}

One of the more recent concerns in Malta's water history was the unequal distribution of water in terms of both water quality and quantity. Measures to improve the distribution of water among all users and stakeholders have been made possible by installing new pipelines to the southern portion of Malta [14]. Further improvements to the distribution of the water supply are being implemented with an additional $32.1 \mathrm{~km}$ of network to southern Malta [20]. This has been a big water-policy step in equality for the people of Malta. Additionally, the blending capacity (mixing of Reverse Osmosis water and groundwater) has been increased, the number of leakages has been reduced, state-of-the-art water 
meters and billing methods have been introduced with harsher penalties for water theft that have led to increased theft detection [14]. The leakages have been reduced from an estimated $2692 \mathrm{~m}^{3} \mathrm{hr}^{-1}$ in 1995 to $650 \mathrm{~m}^{3} \mathrm{hr}^{-1}$ in 2007, representing a great deal of progress, with an estimated $300 \mathrm{~m}^{3} \mathrm{hr}^{-1}$ of unavoidable leakages [6,7]. These leakages have been further reduced to $395 \mathrm{~m}^{3} \mathrm{hr}^{-1}$ as of 2015 [25]. The current domestic demand is about $60 \%$ of what it was in 1992, primarily as a result of the reduction in leakages and partially from the improved efficiency of various water using appliances, toilets, showers, faucets, etc. Meters have been added to almost all of the private, registered boreholes [2]. This enhances the ability to regulate the amount of groundwater being used. A smart grid has also been implemented to govern both water and electricity, making it easier to detect on-going theft, leak, and defective meters, as well as to promote conservative actions [16]. Again, each of these measures is crucial to reaching a sustainable water use in Malta.

A major component of Malta's resolution of their water scarcity challenges comes in the form of Reverse Osmosis water. It is estimated that $60 \%$ of the water supply now comes from this technology (Figure 3) $[1,17,26]$. The three main Reverse Osmosis plants in operation in Malta are located in Ghar Lapsi, Cirkewwa, and Pembroke. These were designed with capacities of 20,000, 18,600, and $54,000 \mathrm{~m}^{3} /$ day, respectively, and were installed from 1981 to 1994 [19]. These plants had recovery rates (the amount of water that goes to be used versus discharged as brine) of $33 \%, 42 \%$, and $45 \%$, respectively, as of 2004 [19]. In 2018, over 19 million $\mathrm{m}^{3}$ of water was produced in total by the three Reverse Osmosis plants, which have been strategically located so that in the event of an oil spill, only one would need to be closed down [2,17]. This strategic planning is important for the country's sustainability. If the plants had not been placed so strategically, the water source could have been seriously compromised, in which case they may have had to completely rely on the already depleting groundwater. Investments are being made to improve the current Reverse Osmosis plants as well as to add an additional plant in Gozo with a capacity of $9000 \mathrm{~m}^{3} /$ day [20]. Through the investments to improve the current Reverse Osmosis plants, it is estimated that 4 billion less liters of water will need to be extracted annually [27]. In terms of energy used for desalinization, immense improvements have been made. Previously, the desalinization of $1 \mathrm{~m}^{3}$ required $6 \mathrm{kWh}$ for treatment in 2008, but only required $2.8 \mathrm{kWh}$ as of 2018. In terms of the resulting brine solution, this is discharged to the sea, where a strong current exists to quickly diffuse the strong saline solution with sea water [2]. To the best of the authors' knowledge, a study of the impact these Reverse Osmosis plants have had on the ecosystems surrounding Malta has not been conducted. However, a lab, field, and long-term study has been conducted to explore the impact of brine solution on the Mediterranean seagrass Posidonia oceanica. The study results indicated that the brine reduced the vitality of the plant and increased the plant mortality [28]. In terms of tourism, it is becoming commonplace for hotels with more than 350 beds to implement their own small Reverse Osmosis system to meet or supplement their needs [7,29]. Overall, these systems are helping to relieve some of the stress on the groundwater aquifers while providing better quality water to the people. 


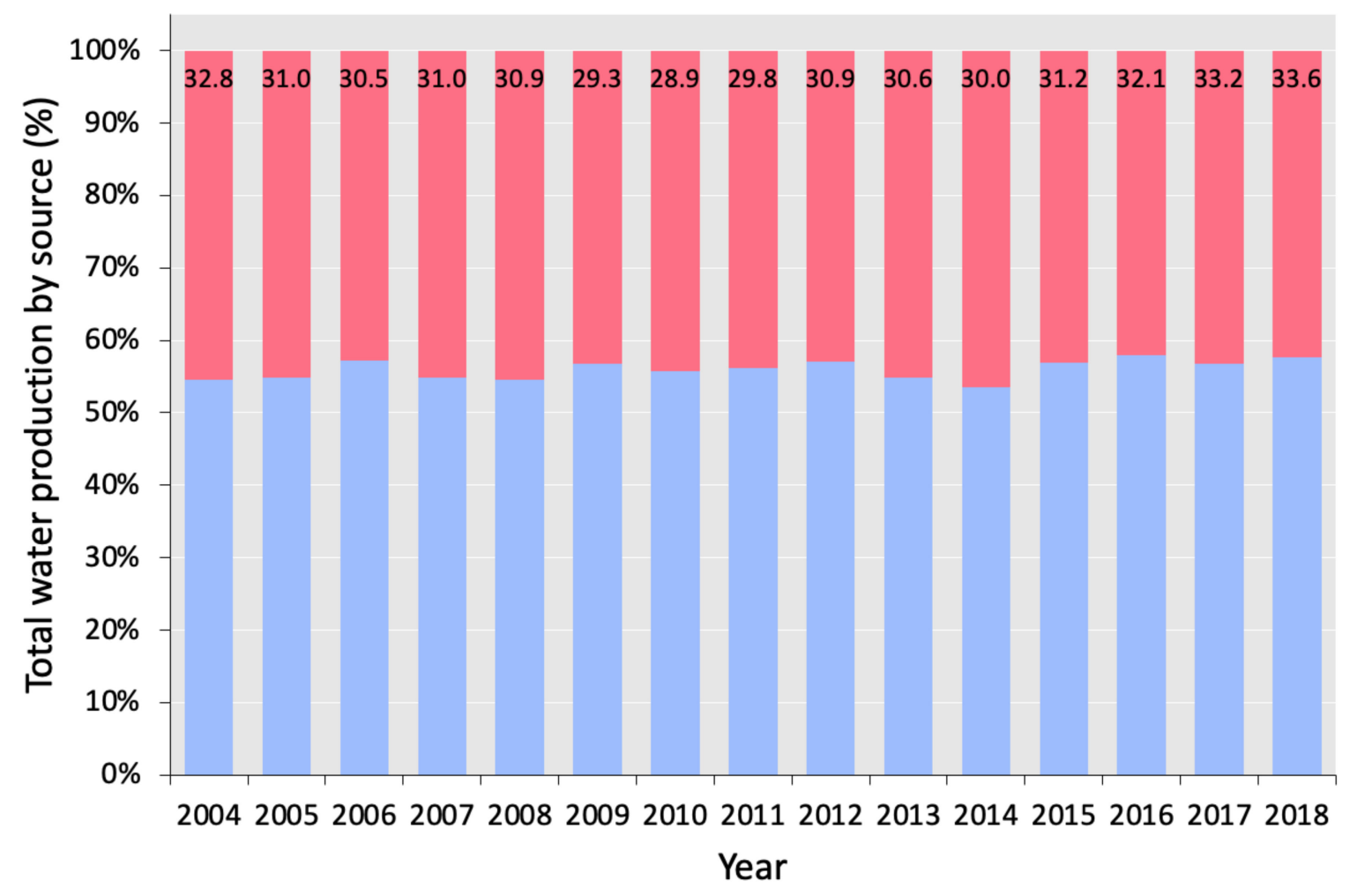

Reverse Osmosis Groundwater

Figure 3. Drinking water source in Malta by category from 2004-2018 modified from [17,26]. The data labels for the columns represent the total water production amounts (million $\mathrm{m}^{3}$ year $^{-1}$ ).

Other countries in the Mediterranean region are facing water stress and have implemented Reverse Osmosis desalination technology as well. Spain has implemented over 20 seawater or brackish water desalination plants just on the Mediterranean coast of the Iberian Peninsula [30]. Greece has 157 operational desalination plants with more being added, nearly $75 \%$ of which use Reverse Osmosis technology. The remaining 25\% of desalination technology in Greece comes in the form of multi-stage flash distillation, multi-effect distillation, and electrodialysis processes [31]. Globally, there are an estimated 15,906 desalination plants with a production capacity of 95.37 million $\mathrm{m}^{3} /$ day as of 2019 [32]. The regions of the Middle East and North Africa contribute to nearly $50 \%$ of this capacity, while the regions of East Asia and the Pacific contribute nearly $20 \%$ more of the total capacity of desalination globally. Other regions that also contribute to the desalination capacity include North America, Western Europe, Latin America, and the Caribbean [32].

Part of caring for the environment is trying to reduce the amount of water used as well. Malta has implemented tiered pricing for their Reverse Osmosis water to try to limit the water use by various stakeholders. The price begins at EUR $1.39 / \mathrm{m}^{3}$ for the first $33 \mathrm{~m}^{3}$ used, after which the price increases to EUR $5.14 / \mathrm{m}^{3}$. The people of Malta typically use $110 \mathrm{~L} /$ day compared to $333 \mathrm{~L} /$ day by citizens in the United States, $132 \mathrm{~L} /$ day and $177 \mathrm{~L}$ /day per person in the nearby countries of Spain and Greece, respectively, or $144 \mathrm{~L} /$ day per person in Europe as a whole [2,33-36]. There is still the potential that this amount could be reduced to $70 \mathrm{~L} /$ day/person by reusing water from showers to flush toilets, but the government needs to ensure this is safe prior to implementation [2]. Increased water prices have been identified as ways to successfully reduce water demand and consumption in other countries [37,38]. The use of groundwater does not include a tiered pricing system though, which limits the reduction of overall water use.

In addition to improving efficiency, other improvements have been added or are currently being added. In terms of wastewater advancements, three wastewater treatment plants were added in the 
late 2000s, which creates an opportunity to reuse treated wastewater by the agricultural and industrial sectors [6]. The treated wastewater can also be released to the sea or potentially be used as a source to replenish the groundwater currently being used, or supplement it at the very least. The industry sector is already slowly introducing water reuse policies and implementing improvements to their water use practices which have led to improved water efficiency [29]. Treated wastewater could represent a constant source of water that could be used for irrigation in the agricultural sector as well.

Environmental programs have also been implemented to improve water management in Malta. A few of these programs include a water conservation campaign (WATER-Be the Change), a River Basin Management Planning, creation of the National Water Conservation Awareness Center, and participation in the LIFE Integrated Project [39]. The water conservation campaign aims to provide education and raise awareness around water use and conservation through a three-year long effort. The water conservation center was opened in 2017 with similar goals. The River Basin Management Planning has a goal of protecting and enhancing the environment as related to water to ensure a sustainable use and development of water resources. Lastly, the LIFE Integrated Project is an eight-year long project lasting from 2018 until 2025. This project is led by the Energy and Water Agency with several partners, and co-financed by the EU LIFE Program. The first phase of this project had the goal of determining goals in Malta's water management, education, and awareness, while the current phase aims to address the general public [39]. Overall, each of these programs aim to increase awareness of the water crisis in Malta to reach a more sustainable future.

In the agricultural sector, improvements have been made in irrigation systems with the introduction of drip/micro irrigation with some overhead sprinkler irrigation systems. This is a change from furrow irrigation, which was a common method of irrigation a few decades ago $[1,6,23,40]$. Malta is now beginning to offer polished treated wastewater to farmers as well as implementing small, in field rainwater storage for water harvesting [2]. The polished wastewater uses ultrafiltration, Reverse Osmosis, and advanced oxidation to further remove bacteria, chemicals, and other pollutants from the already treated wastewater. The Water Services Corporation in Malta refers to this as New Water, and it is expected to produce seven million $\mathrm{m}^{3}$ of water per year [41]. Both the reuse of wastewater and improved efficiency in irrigation technology leads to water conservation and reduces the dependence on the amount of groundwater being used by the agricultural sector. The use of treated or polished wastewater represents a constant source of additional water as well as a nutrient-rich option that could lower fertilizer costs when used for agricultural irrigation [42].

\section{Current and Projected Water, Food, and Energy Security Concerns}

\subsection{Continued Water Security Concerns}

Despite the advances to improve Malta's water scarcity issues, there are still ongoing concerns with both the quantity and quality of water. The main concerns for water quality center around chemical and bacteria pollution such as nitrates, pesticides, and bacterial pollution, as well as health concerns from the growing salinity levels in the groundwater as a result of over pumping and subsequent seawater intrusion [14,23]. In terms of water quantity, the concern is that the groundwater is steadily being depleted despite changes being implemented to reduce water use. One approximation estimates that groundwater is being abstracted $50 \%$ more than is considered to be sustainable [4]. It is estimated that $70 \%$ of Malta is under water stress due to scarcity of water resources and the continually deteriorating quality of groundwater. It is also estimated that $90 \%$ of the groundwater being extracted does not meet the European Union's standards for safe drinking water due to high nitrate levels [13]. In fact, the entire island of Malta is considered as being in a nitrate vulnerable zone [22]. This designation is part of the EU's Nitrate Directive and includes areas of land that either have nitrate levels above $50 \mathrm{mg} / \mathrm{L}$ or are at risk of exceeding this level [43]. Drinking standards were originally set for nitrate levels to limit infant methemoglobinemia, or Blue Baby Syndrome. More recently, epidemiologic studies have linked drinking nitrate-containing waters to colorectal cancer, thryoid disease, and bladder 
cancer [44]. In another watershed with similar climate and rainfall amounts to Malta, bicarbonate $\left(\mathrm{HCO}_{3}\right)$ levels have been observed to be above what is considered suitable for irrigation in their depleting groundwater [45]. This is another parameter that could be evaluated in Malta's groundwater.

There is also concern that climate change will bring added water concerns for Malta in terms of both quality and quantity. Temperatures have generally been trending warmer than what is considered "normal" each year (Figure 4). It is expected that an increase in extreme storm events with greater intensity at shorter durations will occur, leading to less infiltration and more runoff, as well as higher temperatures and lower overall rainfall amounts $[1,3,46]$. With lower infiltration amounts, less groundwater recharge will occur, further exacerbating the current situation. Additionally, there is already as much as $80 \%$ runoff in urban areas compared to $2-5 \%$ in rural areas; to provide perspective roughly $2 / 3$ of the land in Malta is considered to have more urbanized uses $[7,18]$. This represents another area where less groundwater recharge is happening creating further concerns. It is also expected that the sea level will rise due to climate change, raising the level of the saltwater in the aquifers, reducing the amount of freshwater available as well as its storage volume [15]. Climate change has the potential to greatly impact Malta in several ways, placing a further strain on their economy and water scarcity crisis.

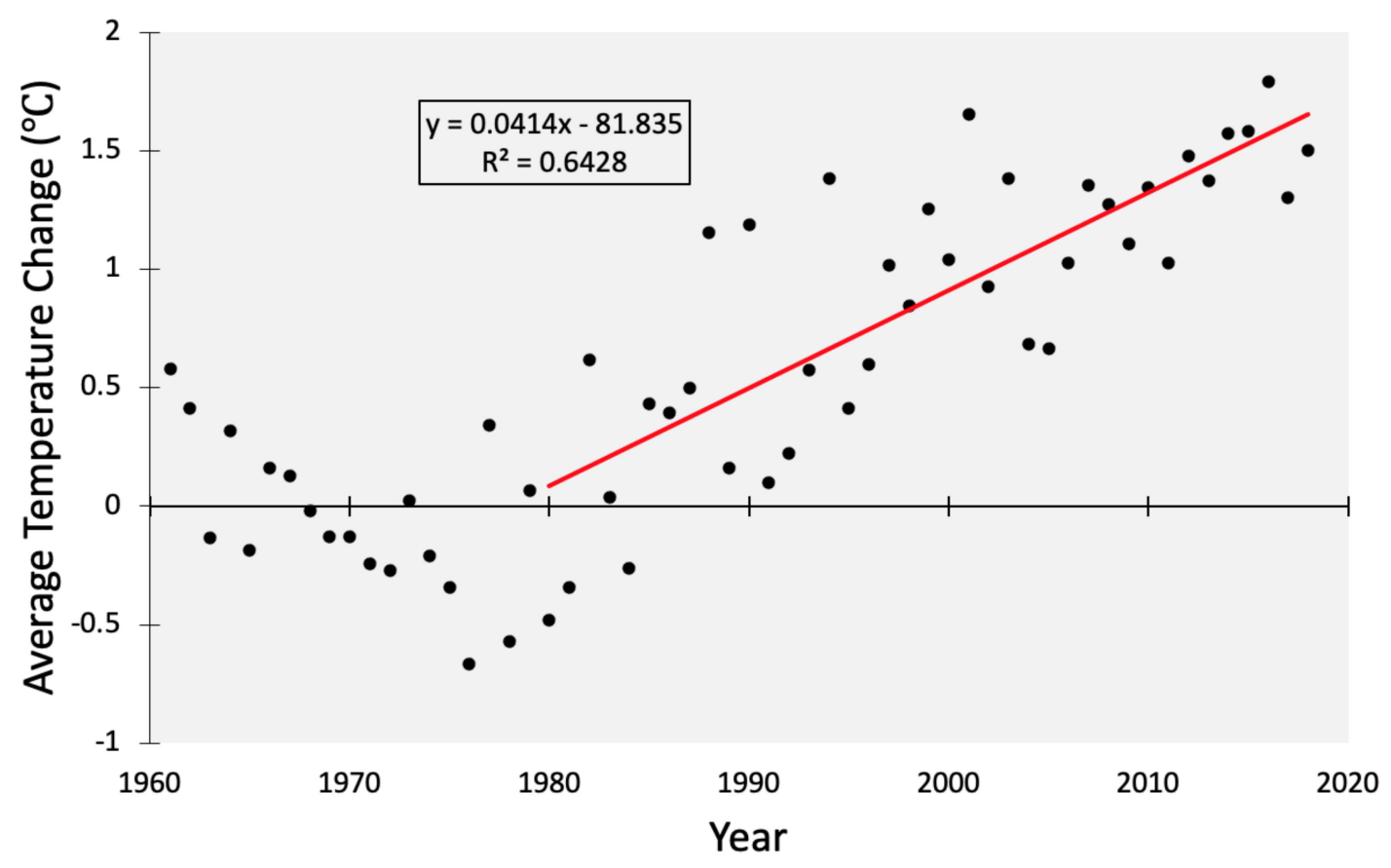

Figure 4. Average temperature change per year in Malta from 1961-2019, modified from [18]. A trendline is presented for the last 30 years of data.

Tiered pricing has been introduced for the Reverse Osmosis water as discussed in the previous section. However, a similar framework has not been added for using groundwater, for which the main cost of using is for pumping the water. The lack of legal framework and low cost of using groundwater has led to greater withdrawal than recharge of groundwater [1,22,29]. The greatest concern and dependence on groundwater is in the agricultural sector. To put it simply, the demands from agriculture, particularly irrigation, cannot be met sustainably through the use of groundwater alone [29]. There are also unknowns about the amount of water being illegally abstracted [22].

Part of the concerns for water quality and quantity in Malta center around the lack of awareness about the issue. A national policy to address the problems does not exist yet, and the public is generally poorly educated on the water issues presently being experienced. The implementation of Reverse Osmosis desalination has provided a sense of water security to the people of Malta, which has not helped to increase awareness of the water scarcity in terms of both quantity and quality that the island 
is facing [8]. There are a series of myths believed by the public such as the limestone naturally removing salts from the groundwater, or that the groundwater is being replenished by the Nile River or other rivers in Europe, meaning they can't over-extract the water [7,15]. This phenomenon is quite concerning when considering the severity of Malta's water problems. More recently, there has been an effort to improve the awareness of the water challenges in Malta through a series of environmental programs such as the LIFE Integrated Project and WATER-Be the Change that have been implemented [39]. In general, the continually depleting quality and quantity or groundwater, lack of legal framework for its use, and general lack of awareness of the water scarcity at hand are of the greatest concern moving forward.

\subsection{Food Security Concerns}

While there are obvious concerns about the quantity and quality of water in Malta, there are equally important concerns for the impact that the groundwater depletion has on Malta's agricultural sector and food security. In Malta, the growing season lasts the entire year, allowing for two or more crops to be grown in a given year depending on the crop rotation [1]. Common crops grown in Malta include wheat, potatoes, and wine grapes at vineyards [3]. Agriculture represents approximately $36.2 \%$ of the land in Malta, while irrigated agricultural land accounts for $15 \%$ of the land and $75 \%$ of the country's total water use, $80 \%$ of which is estimated to come from groundwater [3,7]. However, much of the land that has been irrigated is already considered saline, with salt crystals visible on the soil surface [1]. Salinity in the soil was noticed as early as the 1960s in fields, some of which have since been abandoned due to the buildup of high salinity levels and soil erosion [40]. The decreasing groundwater levels have led to increased salinity, which puts the agricultural sector at a risk, especially the wine grapes, which are more sensitive to the chloride levels that are commonly seen in Malta's groundwater [5]. The salty water prevents the plants from taking up the nutrients in the soil, leading to failure of crops [15].

Presently, soil salinity levels are highest in the summer months, but these do tend to decrease during the winter months from a combination of over irrigation and rainfall [40]. The lack of precipitation coupled with the high evapotranspiration rates correspond to the maximum crop growth period during the summer, meaning that irrigation is needed and the salinity levels in the soil rise [4]. There is hope that the rainier season can flush the salts out of the soil, although this is likely a short term fix, as the salts would likely eventually be returned to the groundwater. Beyond blocking nutrient uptake, soil salinity reduces the soil structure, plant productivity, and affects microorganisms in the soil, which in turn reduces the soil fertility [47]. This is therefore a long-term concern and there is not a simple solution to this problem. The research done in Malta thus far has focused on high salinity from chloride, but other ions with similar impact on soil health include sodium, potassium, magnesium, calcium, sulfate, carbonate, and bicarbonate [47].

The lack of nutrient uptake from high salinity also contributes to the nutrient leaching. Some people may suggest not irrigating the crops in Malta, but due to the lack of rainfall in the summer months (Figure 2), this is not an option for most of the crops grown. By growing potatoes that are irrigated, the economic return is 40 times higher than from unirrigated wheat [40]. Potatoes also serve as one of Malta's most important crops economically as a primary exported crop [4]. While there are concerns about the impact of irrigation on water security, there are also concerns about nutrients leaching into the groundwater. Fertilizer is still necessary to achieve the best yields possible, especially given the salinity problem that exists; a balance is needed though for fertilizer. Applying insufficient fertilizer represents an economic loss to the farmer due to reduced yields, while applying too much represents a water quality concern as well as an economic loss.

Malta is considered a nitrate vulnerable zone, with an estimated $71 \%$ of their groundwater stations having nitrate concentrations at or above $50 \mathrm{mg} / \mathrm{L}$. The EU's Nitrate Directive sets a maximum fertilizer rate of $170 \mathrm{~kg} \mathrm{~N}$ per hectare; if irrigation were considered to be a fertilizer source, this may limit the amount of irrigation from groundwater in Malta [43]. This creates another strain for the productivity 
of agriculture, especially during the typically hot, dry summers experienced. As mentioned in the previous section, treated wastewater represents a potential source to reduce the agricultural sector's groundwater use. Presently, the unpolished treated wastewater is far too saline to use for irrigation; this high salinty comes from brine from some small, private Reverse Osmosis systems that aren't located near the coast being dumped into the city's sewer systems and hotels using seawater for flushing toilets that ends up in the sewage [7]. Therefore, the salinity of the unpolished wastewater is something that will need to be addressed if it is to be the solution to decreasing the agricultural sector's dependence on groundwater. Italy, Greece, Spain, and Portugal have already developed their own standards for reused wastewater with varying levels of strictness [37]. The European Union is currently working to develop a standard for the quality of wastewater including levels for E. coli, biological oxygen demand (BOD), total suspended solids (TSS), and turbidity [48]. This standard is still going through the process of being accepted; it is also worth noting that Malta would likely have to develop its own additional requirements for the wastewater standards to address the high salinity levels in their treated water.

\subsection{Energy Security Concerns}

While Reverse Osmosis now provides a majority of the water for the country and reduces the demand from groundwater, it creates its own set of concerns. This technology has placed a strong dependence on oil imports for both electricity and water; this also sets the price of both electricity and water $[6,16]$. Electricity is estimated to account for roughly three-quarters of the cost for Reverse Osmosis; therefore, as the price of oil increases, so does the price of desalination [16]. It is also anticipated that if the groundwater is continued to be used as it is presently, then even the groundwater would need to be treated by Reverse Osmosis, further increasing the cost of water [16]. The use of Reverse Osmosis technology therefore puts a strain on Malta's economy and increases their carbon footprint [13]. Additionally, while the improved leak detection has helped to offset the expected increase in demand from the rising standard of living, one can expect that eventually the water demand will increase more than the savings [29]. No matter how one looks at it, the dependence on Reverse Osmosis for drinking water has put a dependence on oil to the country with the expectation that this dependence will increase in the future. This information is crucial to the development of water policies to address the current and expected future situations.

Malta has begun to add renewable energy sources, such as photovoltaic systems, but the majority of the energy for the country still comes from fossil fuels. Malta did install 25,000 stocks of photovoltaics in 2018 with a total production of 189.6 GWh [17]. Due to Malta's location in the Mediterranean Sea, it does have potential for wave power as well. The seawater has been determined to be calmer in the area surrounding Malta than other areas of Europe, such as the the north-west region of Europe, but this does have a few advantages. The calmer conditions reduce the risk of breakdown of equipment and over-sizing of equipment during calmer periods of the year [49]. Two studies have identified the north-west region of Malta as being one of the regions with the greatest wave power potenital $[49,50]$. Both solar and wave power should be further explored and implemented to improve Malta's energy security.

\section{Suggested Solutions to Help Reduce the Water, Food, and Energy Concerns}

\subsection{General Solutions Through a Nation-Wide Policy}

While a great amount of work and effort has already been done to improve Malta's water scarcity situation, there is still a long road ahead before Malta reaches a sustainable level of water use. Sacrifices will likely need to be made by some sectors in terms of water use. A nationwide water policy needs to be developed and implemented soon to bring about the necessary changes needed for water use in Malta. The lack of governance as well as fragmented policies for each sector are not helping the water crisis in Malta; this has resulted in haphazard decision-making and limited awareness of the 
seriousness of the water concerns that the country is facing [1]. Recently, environmental programs have been implemented with the goal of improving public awareness of the water crisis in Malta [39]. While these programs provide a starting point for improvement, a nation-wide policy is still warranted. Before an effective policy can be created, better information is needed on the current quality and quantity of groundwater, as well as how it is being used [22]. Without this information, it will be difficult to create an effective water policy considering the current water uses and where reductions in water use need to be made. A nation-wide policy would need to establish efficient water governance to regulate water uses and sources while taking into account the social, economic, and environmental benefits and impacts that come from each sector's uses as well as considering climate change $[1,7]$. This policy should address groundwater monitoring, the inadequate understanding of how salinity impacts crop yields, and water quality issues from leaching through guidance on irrigation schedules, improved water use and efficiencies, as well as promoting rainwater storage [22]. As part of the policy that should be created, practices or mitigation techniques to prevent water wasting during drought conditions are needed [29]. Farmers will need to be included in any water policies created as well. Farmers may not be the greatest contributors to the nation's GDP, but the farms do support many rural families, the food security, and tourism in Malta [4]. A policy to address the current water crisis in Malta is clearly warranted, with many factors needing to be included to make it effective.

No matter how one looks at the situation, reductions in water use, especially groundwater, are needed in order to be sustainable and achieve water, food, and energy security. If limits or reductions to water use are to be achieved, a good place to start would be sites with the greatest groundwater abstractions. Specifically, this might mean locating boreholes with high groundwater abstractions, licensing them, and metering them to have a greater idea of their water use and impose restrictions [28]. Another approach to limit groundwater use would be to increase the cost of groundwater to a point where people would want or need to reduce their use [7]. This could come in the form of a tariff or other demand-management techniques [22]. Any tariffs introduced would need to be high enough to encourage interest in improving efficiencies, using alternative water sources, or discouraging water use for non-essential activities. Either way, some type of groundwater management is needed to ensure that the abstracted water is being used responsibly and efficiently.

A positive alternative to groundwater is harvesting rainwater from runoff. In households and businesses, harvested rainwater could be used for both, groundwater recharge as well as flushing purposes to reduce the amount of groundwater or Reverse Osmosis water being used. It's estimated that a $25 \mathrm{~m}^{3}$ cistern per household would provide $40 \%$ of the billed domestic water use; the main problems to overcome are the cost to implement and that most of the rainfall comes in a short period of time $[7,8]$. The harvested rainwater, as well as reused treated wastewater, could replace groundwater for irrigation if incentive-based policies are developed for the farmers [6]. When considering treated wastewater as an option for irrigation, there would also need to be storage created to maximize its use, since the treated wastewater is a consistent, constant source of additional water, while irrigation is seasonal $[7,29]$. Infrastructure is likely needed as well to supply the treated wastewater to end-users. The other option with treated wastewater would be to use it to recharge aquifers during the times when irrigation demand does not meet the effluent supply [7]. Whether considering rainwater storage or treated wastewater as an alternative source of water, these need to be incentivized [4]. Without developing incentive based policies to encourage the use of alternative water sources, people will continue their business as usual.

To reduce the country's dependence on oil and potentially reduce the added cost for Reverse Osmosis, it is recommend that the country continues to invest in renewable energy. With Malta's climate and location, solar and wave energy could be quite successful and would lower their carbon footprint. The country's energy security would be improved by being in control of their energy supply. Each of these strategies need to be evaluated and prioritized; this eventually could lead to a sustainable water use level in Malta. 


\subsection{Agriculture Specific Solutions}

Many of the changes that are needed will have to come from the agricultural sector, as it is the greatest user of water in Malta. Before the agricultural sector is able to improve its efficiencies, guidance is needed from experts. An exchange of knowledge and ideas from collaboration is warranted, as well as a promotion of best management practices and innovative technologies which could come from field days which currently don't exist $[1,4,22]$. There are a few simple strategies which may be able to help farmers in terms of nutrient management. One study suggested the use of strip tests for nitrate, ammonium, and chloride through a handheld device that could be cost-shared by local farmers to get a quick assessment of the current soil parameters to inform farmers about making nutrient application decisions. Another factor that would help reduce both concerns for nutrient or pesticide leaching and water use is to improve soil moisture monitoring to optimize irrigation. An option that would be costly but beneficial is variable rate irrigation using soil sensors [1]. In the water scarce country of Malta, this technology has tremendous potential to reduce water use and leaching. Coinciding with the improvement of irrigation is the improvement of the soil conditions. Through increased organic matter or cover crops, the surface of the soil is protected, reducing the erosion potential, and improving infiltration, which is critical for groundwater recharge.

Other changes that could come to the agricultural sector to reduce water use are centered around the idea of reducing the crop's water requirements. A realistic approach would be to develop and grow new crop varieties more suited to Malta's conditions while also implementing new crop rotations to improve the soil management [22]. Different crop types may also need to be grown in Malta than are currently grown that are more drought or saline tolerant. This may result in a lower economic return, but greater wateruse efficiency, leading to water security and as a result, food and energy security. Growing crops in a controlled environment such as greenhouses could be explored; in the most extreme case, crops could be grown during the summer months in controlled environments when irrigation demand would be too high to grow the same crop in an open environment. The formation of an extension service could address the lack of knowledge on the crop water requirements and soil characteristics as well, providing several benefits to Malta [4].

One of the strongest suggestions has been for agricultural irrigation to use treated wastewater. For this to be feasible though, a greater quantity of highly polished wastewater is needed through the existing technology to bring the wastewater to a useable level or standard [13,40,41]. Again, infrastructure is needed to make this possible, as well as potential storage systems for the treated effluent. This could be used to recharge the aquifers as well $[13,16,40]$. Another option is to mix desalinated water with groundwater, which could reduce the stress currently on the aquifers [5]. This strategy has again been proposed as a way to generate greater yields and economic returns in agriculture. By irrigating with lower salinity water by mixing Reverse Osmosis and groundwater 50/50, a $25 \%$ increase in yield is possible [5]. This option may have considerable costs for the infrastructure that would be needed to deliver desalinated water to be mixed with groundwater. The literature reviewed did not discuss the extent of the Reverse Osmosis water's network, so it is difficult to definitively say how much of an economic burden this may create for Malta. This option may also still make use of groundwater that's been treated which does not address the water scarcity issues. To truly become more sustainable, the amount of groundwater used needs to be reduced to lower salinity levels. Additionally, sharing of resources among farmers is becoming additionally difficult due to the fragmentation of farmland [4]. As more of the land turns to urbanized uses, the farmland has become more spread out. The location of the brine discharge would need to be evaluated to weigh the impact on the ecosystem that this option might have as well. Either way, this is something that should be explored to reduce Malta's water scarcity problem. Hope remains that Malta can reach a level of water security, and as a result, both food and energy security too.

There is a real need to lower the water use, but also energy used in crop production. Soil and weather monitoring stations should also be established with the information gathered being shared with farmers to provide better crop information [4]. Without this information, it is difficult for them 
to determine opportunities for improvement. It should be noted that there are a few obstacles in the agricultural sector to overcome before new technologies or strategies can be adopted as well. These include a general lack of trust or cooperation, high costs to implement new technologies or storage, continued land fragmentation making sharing of technology more difficult, the large number of small, individual farms, and the aging demographic [22]. These problems will also need to be addressed and worked on to reach water security.

\section{Conclusions}

The small island country of Malta has had a long history of water challenges, typically in terms of water quantity. More recently, the water quantity issues have also turned into a water quality problem. The water quality has deteriorated from over-extraction of groundwater, leading to saltwater intrusion and subsequent high salinity levels. Additionally, leaching of nutrients and pesticides from agriculture to groundwater have occurred, further deteriorating the quality of Malta's groundwater. Several measures have been taken recently to improve water security challenges. These include massive water leakage mitigation in the piping systems, investments in improved metering and smart grids, Reverse Osmosis plants and infrastructure for distribution, wastewater treatment plants, and additional water conservation practices. Recently, environmental programs such as the LIFE Integrated Program, River Basin Management Planning, and WATER-Be the Change have been implemented to increase the awareness of the water challenges in Malta. Despite the investments made in improving water leakages, treating seawater to reduce groundwater use, and in environmental programs, unsustainable water use is still occurring. The deteriorating quantity and quality of water has threatened the agricultural sector and both food and energy security of Malta. Many of the crops grown in Malta cannot be grown during the peak growing season without irrigation, which has been hindering crop growth due to the rising salinity levels of soils; this also threatens the existing groundwater reserves because of over abstraction.

Due to these concerns and having significant efforts made on improving water infrastructure, future measures and policies will be needed to solve the water scarcity crisis in Malta. In our opinion, a national water policy to limit/regulate water use, increase the awareness of the current water scarcity situation through education, improve infrastructure, and create more robust alternative water sources such as treated wastewater for agriculture, is needed as well as prioritization of each water use sector in Malta. Through this policy, improvements to technology advancements and guidance should be delivered, especially to the greatest water user, agriculture. Alternative water sources such as rainwater harvesting have a great potential for enhancing the availability of good quality water for all sectors including the domestic sector. Treated wastewater reuse may be one of the best the solutions in lowering agriculture's dependence on groundwater in Malta if it is of sufficient quality to be used as irrigation water. This may require additional infrastructure as well. Other areas of importance are the creation of extension educational services for farmers in guiding them on precise use of water for different agricultural crops. There is huge potential in Malta to grow less water intensive crops, either through crop genetics or growing crops better suited to the climate in Malta; in addition, controlled environment agriculture such as greenhouses could be explored. In the most extreme case, crops could be grown during the summer months in controlled environments when irrigation demand would be too high to grow the same crop in an open environment. Lastly, as Reverse Osmosis has become such a vital part of Malta's battling water security problems, renewable energy should be a priority. Malta currently depends on oil imports for energy, which fluctuates with prices and availability. Further investments in renewable energy would truly help improve both the energy and water security problems. There is still hope that Malta can become sustainable in their water use and achieve water, food, and energy security. Actions and sound incentive policies are needed before the three pillars of life in Malta are further jeopardized. The solutions outlined in this article are transferrable to other European countries of similar climate, water stress, and proximity to seawater. 
Author Contributions: Conceptualization, writing—original draft preparation L.H.; writing—review and editing, R.S.K. and M.S.; supervision, R.S.K. and M.S.; project administration, R.S.K. All authors have read and agreed to the published version of the manuscript.

Funding: The material in this paper is based upon work supported by the US National Science Foundation under Grant No. DGE-1828942. Any opinions, findings, and conclusions or recommendations expressed in this material are those of the author(s) and do not necessarily reflect the views of the National Science Foundation.

Acknowledgments: This paper was written for the course "ABE 690: Biosystems for Sustainable Development" at Iowa State University.

Conflicts of Interest: The authors declare no conflict of interest. The funders had no role in the design of the study; in the writing of the manuscript, or in the decision to publish the results.

\section{References}

1. Hallett, S.H.; Sakrabani, R.; Thomas, A.J.; Deeks, L.K.; Knox, J. Improving soil and water management for agriculture: Insight and innovation from Malta. MCAST J. Appl. Res. Pract. 2017, 1, 40-59. [CrossRef]

2. Sapiano, M. Interview-Malta: Water Scarcity is a Fact of Life. Available online: https://www.eea.europa.eu/ signals/signals-2018-content-list/articles/interview-2014-malta-water-scarcity (accessed on 23 January 2020).

3. Fenech, S.; Knox, J.; Borg, M.; Camilleri, C.; Rizzo, A. Estimating impacts of land use change on evapotranspiration for three agricultural crops in Malta-A preliminary assessment. JAS 2019, 11, 67. [CrossRef]

4. Papadimitriou, L.; D’agostino, D.; Borg, M.; Hallett, S.; Sakrabani, R.; Thompson, A.; Knox, J. Developing a water strategy for sustainable irrigated agriculture in Mediterranean island communities-Insights from Malta. Outlook Agric. 2019, 48, 143-151. [CrossRef]

5. Aparicio, J.; Tenza-Abril, A.J.; Borg, M.; Galea, J.; Candela, L. Agricultural irrigation of vine crops from desalinated and brackish groundwater under an economic perspective. A case study in Sigigiewi, Malta. Sci. Total Environ. 2019, 650, 734-740. [CrossRef]

6. Sapiano, M. Measures for facing water scarcity and drought in Malta. Eur. Water 2008, 23/24, 79-86.

7. FAO. Malta Water Resources Review; Food and Agriculture Organization of the United Nations: Rome, Italy, 2006.

8. Reitano, R. Water Harvesting and Water Collection Systems in Mediterranean Area. The case of Malta. Procedia Eng. 2011, 21, 81-88. [CrossRef]

9. E.E.A. 2. Semi-Arid Areas in the EEA Area. Available online: https://www.eea.europa.eu/publications/929167-056-1/page003.html (accessed on 25 October 2020).

10. Collet, L.; Ruelland, D.; Estupina, V.B.; Dezetter, A.; Servat, E. Water supply sustainability and adaptation strategies under the anthropogenic and climatic changes of a mess-scale Mediterranean catchment. Sci. Total Environ. 2015, 536, 589-602. [CrossRef]

11. Matte, D.; Larsen, M.A.D.; Christensen, O.B.; Christensen, J.H. Robustness and scalability of regional climate projections over europe. Front. Environ. Sci. 2019, 6, 163. [CrossRef]

12. Luck, M.; Landis, M.; Gassert, F. Aqueduct Water Stress Projections: Decadal Projections of Water Supply and Demand Using CMIP5 GCMs; World Resources Institute: Washington, DC, USA, 2015.

13. Spiteri, D.; Scerri, C.; Valdramidis, V. The current situation for the water sources in the Maltese islands. Malta J. Health Sci. 2015, 25, 22-25. [CrossRef]

14. Birdi, N. Water scarcity in Malta. GeoJournal 1997, 41, 181-191. [CrossRef]

15. Striebig, B.A.; Ogundipe, A.A.; Papadakis, M. Engineering Applications in Sustainable Design and Development; Cengage Learning: Boston, MA, USA, 2016.

16. Goldstein, H. Malta takes control. IEEE Spectr. 2010, 47, 65-71. [CrossRef]

17. National Statistics Office. Regional Statistics Malta: 2020 Edition. Available online: https://nso.gov.mt/en/publicatons/Publications_by_Unit/Documents/02_Regional_Statistics_(Gozo_ Office)/2020/Regional_Statistics_Malta-2020\%20Edition.pdf (accessed on 17 September 2020).

18. FAO. FAOSTAT Statistical Database. Available online: http://www.fao.org/faostat/en/\#data/ET (accessed on 17 September 2020).

19. World Bank Group. Seawater and Brackish Water Desalination in the Middle East, North Africa and Central Asia: A Review of Key Issues and Experience in Six Countries (Vol. 6): Annex 5-Malta; World Bank Group: Washington, DC, USA, 2004. 
20. Commission, E. Improving Water Quality and Waste Water Infrastructure in Malta. Available online: https://ec.europa.eu/regional_policy/en/projects/Malta/improving-water-quality-and-waste-waterinfrastructures-in-malta (accessed on 2 November 2020).

21. Group, W.B. Climate Change Knowledge Portal. Available online: https://climateknowledgeportal. worldbank.org/country/malta/climate-data-historical (accessed on 17 September 2020).

22. D’agostino, D.; Borg, M.; Hallett, S.H.; Sakrabani, R.S.; Thompson, A.; Papadimitriou, L.; Knox, J.W. Multi-stakeholder analysis to improve agricultural water management policy and practice in Malta. Agric. Water Manag. 2020, 229, 105920. [CrossRef]

23. Micallef, P.; Attard, G.; Mangion, J. Water resources management in Malta: Cultural heritage and legal and administrative set-up. Cent. Int. Hautes Etudes Agron. Mediterr. 2000, 48, 199-207.

24. Bremere, I.; Kennedy, M.; Stikker, A.; Schippers, J. How water scarcity will effect the growth in the desalination market in the coming 25 years. Desalination 2001, 138, 7-15. [CrossRef]

25. Corporation, W.S. Water Production. Available online: http://www.wsc.com.mt/about-us/water-productiondistribution/ (accessed on 24 October 2020).

26. National Statistics Office. News Release; National Statistics Office: Lascaris, Valletta, Malta, 2014.

27. Commission, E. Investment Set to Drastically Improve Water Sustainability in Malta. Available online: https:/ec.europa.eu/regional_policy/en/newsroom/news/2019/04/17-04-2019-investment-set-to-drasticallyimprove-water-sustainability-in-malta (accessed on 2 November 2020).

28. Sánchez-Lizaso, J.L.; Romero, J.; Ruiz, J.; Gacia, E.; Buceta, J.L.; Invers, O.; Fernández Torquemada, Y.; Mas, J.; Ruiz-Mateo, A.; Manzanera, M. Salinity tolerance of the Mediterranean seagrass Posidonia oceanica: Recommendations to minimize the impact of brine discharges from desalination plants. Desalination 2008, 221, 602-607. [CrossRef]

29. Borg, D.S. An application of drought indices in Malta, Case Study. Eur. Water 2009, 25/26, $25-38$.

30. Pulido-Bosch, A.; Vallejos, A.; Sola, F. Methods to supply seawater to desalination plants along the Spanish mediterranean coast and their associated issues. Environ. Earth Sci. 2019, 78, 1-9. [CrossRef]

31. Zotalis, K.; Dialynas, E.; Mamassis, N.; Angelakis, A. Desalination Technologies: Hellenic Experience. Water 2014, 6, 1134-1150. [CrossRef]

32. Jones, E.; Qadir, M.; Van Vliet, M.T.H.; Smakhtin, V.; Kang, S.-M. The state of desalination and brine production: A global outlook. Sci. Total Environ. 2019, 657, 1343-1356. [CrossRef]

33. EPA, U.S.E.P.A.U. Water Sense Statistics and Facts. Available online: https://www.epa.gov/watersense/ statistics-and-facts (accessed on 18 September 2020).

34. Agency, E.E. Water Use in Europe-Quantity and Quality Face Big Challenges. Available online: https://www.eea.europa.eu/signals/signals-2018-content-list/articles/water-use-in-europe-2014\#: \{\}: text=On \%20average \%2C\%20144\%20litres\%20of,supplied $\% 20$ to $\% 20$ households $\% 20 \mathrm{in} \% 20$ Europe (accessed on 25 October 2020).

35. Forte, F. Average Daily Water Consumption Per Inhabitant in Spain from 2000 to 2018. Available online: https://www.statista.com/statistics/801686/per-capita-daily-water-consumption-in-spain/ (accessed on 3 November 2020).

36. Heggie, J. Preventing a Water Crisis in Greece. Available online: https://www.nationalgeographic.com/ science/2020/05/partner-content-where-our-water-goes-greece/ (accessed on 3 November 2020).

37. Lavrnić, S.; Zapater-Pereyra, M.; Mancini, M. Water Scarcity and Wastewater Reuse Standards in Southern Europe: Focus on Agriculture. Water Air Soil Pollut. 2017, 228, 1-12. [CrossRef]

38. Collins, R.; Kristensen, P.; Thyssen, N. Water Resources across Europe-Confronting Water Scarcity and Drought; European Environment Agency: Copenhagen, Denmark, 2009; Volume 2.

39. Agency, T.E.W. Water. Available online: https://www.energywateragency.gov.mt/water/ (accessed on 2 November 2020).

40. Vella, S.J.; Camilleri, S. Irrigated agriculture and soil salinization in the Maltese Islands. J. Environ. Sci. Health 2003, 38, 1569-1585. [CrossRef] [PubMed]

41. Corporation, W.S. New Water. Available online: http://www.wsc.com.mt/information/new-water/ (accessed on 24 October 2020).

42. Molinos-Senante, M.; Hernández-Sancho, F.; Sala-Garrido, R. Cost-benefit analysis of water-reuse projects for environmental purposes: A case study for Spanish wastewater treatment plants. J. Environ. Manag. 2011, 92, 3091-3097. [CrossRef] [PubMed] 
43. Commission, E. Report from the Commission to the Council and the European Parliament on Implementation of Council Directive 91/676/EEC Concerning the Protection of Waters against Pollution Caused by Nitrates from Agricultural Sources Based on Member State Reports for the Period 2012-2015. Available online: https://www.actu-environnement.com/media/pdf/news-31230-rapport-pollution-nitratescommission-europeenne.pdf (accessed on 16 September 2020).

44. Ward, M.; Jones, R.; Brender, J.; De Kok, T.; Weyer, P.; Nolan, B.; Villanueva, C.; Van Breda, S. Drinking water nitrate and human health: An updated review. Int. J. Environ. Res. Public Health 2018, 15, 1557. [CrossRef]

45. Purushotham, D.; Prakash, M.R.; Narsing Rao, A. Groundwater depletion and quality deterioration due to environmental impacts in Maheshwaram watershed of R.R. district, AP (India). Environ. Earth Sci. 2010, 62, 1707-1721. [CrossRef]

46. La Jeunesse, I.; Cirelli, C.; Aubin, D.; Larrue, C.; Sellami, H.; Afifi, S.; Bellin, A.; Benabdallah, S.; Bird, D.N.; Deidda, R.; et al. Is climate change a threat for water uses in the Mediterranean region? Results from a survey at local scale. Sci. Total Environ. 2016, 543, 981-996. [CrossRef] [PubMed]

47. de Souza Silva, C.M.M.; Fay, E.F. Effect of Salinity on Soil Microorganisms. In Soil Health and Landuse Management; Hernandez-Soriano, M.C., Ed.; InTech: Rijeka, Croatia, 2011; pp. 177-182.

48. Halleux, V. Water reuse: Setting minimum requirements. In European Parliament: EU Legislation in Progress; European Union: Brussels, Belgium, 2020; Available online: https:/www.europarl.europa.eu/RegData/ etudes/BRIE/2018/625171/EPRS_BRI(2018)625171_EN.pdf (accessed on 24 October 2020).

49. Franzitta, V.; Curto, D.; Milone, D.; Rao, D. Assessment of renewable sources for the energy consumption in Malta in the Mediterranean Sea. Energies 2016, 9, 1034. [CrossRef]

50. Drago, A.; Azzopardi, J.; Gauci, A.; Tarasova, R.; Bruschi, A. Assessing the offshore wave energy potential for the Maltese islands. In Proceedings of the Sustainable Energy 2013: The ISE Annual Conference, Qawra, Malta, 21 March 2013.

Publisher's Note: MDPI stays neutral with regard to jurisdictional claims in published maps and institutional affiliations.

(C) 2020 by the authors. Licensee MDPI, Basel, Switzerland. This article is an open access article distributed under the terms and conditions of the Creative Commons Attribution (CC BY) license (http://creativecommons.org/licenses/by/4.0/). 